ТІЛЕСНО-ОРІЕНТОВАНИЙ ПІДХІД ДО ПСИХОДІАГНОСТИКИ

ТА ПСИХОКОРЕКЦІЇ ЕМОЦІЙНОГО ІНТЕЛЕКТУ У ПІДЛІТКІВ IЗ ПОРУШЕННЯМИ РОЗУМОВОГО РОЗВИТКУ

\title{
BODY-ORIENTED APPROACH TO PSYCHOLOGICAL DIAGNOSTICS AND PSYCHOLOGICAL CORRECTION OF EMOTIONAL INTELLIGENCE IN ADOLESCENTS WITH MENTAL DEVELOPMENT
}

У статті розглянуто тілесно-орієнтовану психологію як групу методів не лише для психотерапії чи психокорекції емоційноі сорери підлітків з порушеннями розумового розвитку, а й з метою психодіагностики. Тілесно-орієнтований підхід у роботі з підлітками зазначеної категорії спрямований на вивчення тіла, усвідомлення тілесних відчуттів, на дослідження того, як потреби, бажання і почуття проявляються у різних тілесних станах, і на навчання відповідних, прийнятних способів вирішення порушень у цій сорері. Автором наголошено, що саме тілесно-орієнтовані методики у роботі з підлітками з порушеннями розумового розвитку є ефективними та дієвими, оскільки тілесний досвід $є$ необхідним складником людського існування, умова його повноти і цілісності. Крім того, тіло підлітка виступає каналом і способом впливу на структуру його особистості. У статті також охарактеризовано особливості психодіагностики та психокорекції у тілесно-орієнтованій психології в роботі з підлітками з порушеннями розумового розвитку. Автором проведено психодіагностичну процедуру дослідження стану сорормованості емоційного інте лекту підлітків з порушеннями розумового розвитку методиками тілесно-орієнтованої психології. Сфрормовано основні рекомендаціі щодо психокорекційних заходів з формування емоційного інтелекту у підлітків з порушеннями розумового розвитку техніками тілесно-орієнтованоїтерапії. Устаттізазначено, що у підлітків з порушеннями розумового розвитку використання зазначеного виду терапії буде доцільним із метою не лише формування емоційного інтелекту, а й для зниження рівня агресивності, психокорекціі алекситимічних проявів у підлітків, акцентуйованих рис особистості та невротизації. Під час психотерапевтичної та психокорекційної роботи з підлітками з порушеннями розумового розвитку було використано техніки дихання, робота з м'язами, ігри, рухові вправи, обговорення емоиійних переживань під час ігор, обговорення больових відчуттів. Ключові слова: підлітковий вік, порушення розумового розвитку, тілесно-орієнтована терапія, емоційний інтелект, психодіагностика, психокорекція.

The article considers body-oriented psychology as a group of methods not only for psychotherapy or psychocorrection of the emotional sphere of adolescents with mental development, but also for psychodiagnostics. The body-oriented approach in working with adolescents of this category is aimed at studying the body, awareness of bodily sensations, to study how needs, desires and feelings are manifested in different bodily states, and to teach appropriate, acceptable ways to solve disorders in this area. The author emphasizes that it is body-oriented techniques in working with adolescents with mental development are effective and efficient, because physical experience is a necessary component of human existence, a condition of its completeness and integrity. In addition, the body of the adolescent acts as a channel and a way to influence the structure of his personality. The article also describes the features of psychodiagnostics and psychocorrection in body-oriented psychology in working with adolescents with mental development. The author conducted a psychodiagnostic procedure to study the state of formation of emotional intelligence of adolescents with mental development using the methods of body-oriented psychology. The main recommendations for psycho-corrective measures for the formation of emotional intelligence in adolescents with mental development by techniques of body-oriented therapy. The article states that in adolescents with mental development the use of this type of therapy will be appropriate not only to form emotional intelligence, but also to reduce aggression, psychocorrection of alexithymic manifestations in adolescents, accentuated personality traits and neuroticism. During psychotherapeutic and psychocorrectional work with adolescents with mental development, breathing techniques, work with muscles, games, motor exercises, discussion of emotional experiences during games, discussion of pain were use. Key words: adolescence, mental development disorders, body-oriented therapy, emotional intelligence, psychodiagnostics, psychocorrection. наук України

Постановка проблеми. На сучасному етапі розвитку спеціальної психології $€$ широкий спектр психологічних технологій із надання психологічної допомоги, формування психологічного супроводу, корекції та розвитку особистості підлітків. Представники мультимодального підходу В. Атітова, Г. Демиренко, Б. Мороз та інші зазначали, що для ефективної роботи з підлітками з порушеннями розумо- вого розвитку доречно використовувати широкий спектр психокорекційних і терапевтичних технологій, їхню «... інтеграцію та комбінування один з одним з метою більш повного та якісного впливу на формування особистості» [3; 4].

Український дослідник В. Стариченко як представник мультикомплексного підходу зазначав, що успішність підбору технологій психологічного впливу залежить від емоцій- 
ного включення суб'єкта впливу. Емоційне включення визначає ефективність методики. Так, учений виділив низку характеристик, «наявність яких забезпечує той чи інший ступінь емоційного включення підлітка в психотерапевтичну чи психокорекційну діяльність» [6, с. 48]. Так, чим більшу кількість параметрів представлено в певній вправі, тим більшою мірою вона сприятиме формуванню того чи іншого функціонального стану. До цих характеристик належать: ритм і темп вправи (музика, вислови-цитати, танець, пластико-драматичні дії); зміст (текст, казка, малюнок, фотографія, колаж); форма (малюнок, скульптура, колаж, пластиково-рухова композиція); складність використання та доцільність для підлітка. Наявність усіх перелічених характеристик в одній вправі чи методиці сприяє результативності й «екологічності» використання її психологом у роботі з підлітком.

Феномен психодіагностики та психокорекції емоційного інтелекту полягає у сутності розуміння емоційного інтелекту, його природи. З одного боку, емоційний інтелект пов'язаний з когнітивними здібностями, а з іншого - з особистісними характеристиками. Так, операціоналізацією емоційно-інтелектуального конструкту емоційного інтелекту займалися такі вчені, як І. Андрєєва, О. Власова, Г. Гарскова, Д. Карузо, Д. Люсін, Дж. Майер, Р. Робертс та П. Саловей У ході дослідження емоційний інтелект буде розглянуто нами як особистісна характеристика, як частина емоційної сфери особистості, саморегуляційний конструкт. Оскільки для роботи з підлітками з порушеннями розумового розвитку важливим та актуальним для становлення особистості $€$ формування здатності підлітка до усвідомлення, вираження та вербалізації власних емоцій; формування диференціації образу «я»; формування самоконтролю за власними емоціями та емоційними станами; формування адекватної самооцінки; розвиток комунікативних навичок соціальної взаємодії. Основними завданнями тілесно-орієнтованої психології в контексті формування емоційного інтелекту, його психодіагностики, подальшої психокорекції певних аспектів емоційного інтелекту $€$ формування диференціації образу «я», формування самоконтролю та емоційного контролю, здатності до усвідомлення та вербалізації власних емоцій, почуттів, потреб тощо.

Метою статті $€$ теоретичне та емпіричне дослідження використання психодіагностичних та психокорекційних технік тілесно-орієнтованої терапії у формуванні емоційного інтелекту підлітків з порушеннями розумового розвитку. Відповідно до поставленої мети визначено такі завдання:

- встановити особливості психодіагностики та психокорекції у тілесно-орієнтованій психології в роботі з підлітками з порушеннями розумового розвитку;

- провести психодіагностику емоційного інтелекту підлітків з порушеннями розумового розвитку методиками тілесно-орієнтованої психології;

- сформувати основні рекомендації з психокорекційних заходів щодо формування емоційного інтелекту у підлітків 3 порушеннями розумового розвитку техніками тілесно-орієнтованої психології.

Виклад основного матеріалу. У психологічній практиці та наукових пошуках тілесно-орієнтований підхід у роботі 3 дітьми та підлітками досліджували Ф. Александер, Д. Боаделла, Т. Байкін, Д. Голмен, А. Лоуен, Д. Прайс, В. Райх, І. Рольф, М. Фельденкрайз, А. Янов, Т. Ханна $[1 ; 7 ; 8 ; 5]$. Більшість сучасних психологів використовують методики тілесно-орієнтованої психології в практичній роботі з дітьми та підлітками з порушеннями психофізичного розвитку, зокрема і в роботі з підлітками з порушеннями розумового розвитку, але в сучасній спеціальній психології цьому напряму приділяється не досить уваги та розробок. Зокрема, у своїх роботах Т. Байкін виділяє основні фактори, які $€$ причинами використання психологами методів тілесно-орієнтованої терапії у роботі з підлітками з порушеннями розумового розвитку: по-перше, тілесний досвід є необхідним складником людського існування, умова його повноти і цілісності; по-друге, тіло сприймається своєрідним втіленням структури особистості та психологічних проблем; по-третє, тіло виступає каналом і способом впливу на особистість [1, с. 156-158].

Часто в роботі з підлітками з порушеннями розумового розвитку нівелюють значення методів тілесної психології, зводячи її до фізичної культури. Варто зазначити, що саме тілесно-орієнтований підхід має істотні переваги над іншими психотерапевтичними та психодіагностичними підходами, зокрема: техніки тілесно-орієнтованого підходу не піддаються критично-оцінювальному аналізу свідомості людини, а отже, діють швидше й ефективніше за вербальні методи, прийоми тілесно-орієнтованої психології дають змогу дуже делікатно працювати з основою психологічних проблем, про які іноді людина не хоче розповідати чи й загалом усвідомлювати.

Психолог В. Райх, засновник тілесної терапії, зазначав, що будь-які емоційні порушення, зокрема низький рівень емоційного інтелекту або його часткова сформованість у особистості з порушеннями розумового розвитку, спричинені тілесними та м'язовими «утисками» або, як зазначав учений, «м'язовими панцирами». Руйнування «м'язового панцира» дає змогу впливати на особистість та її емо- 
ційний стан, поведінку, самоконтроль та емоційний контроль, стратегії, змінюючи їх на більш соціально прийнятні або такі, що позитивно впливають на функціонування та розвиток особистості. «Робота з тілом, - зазначав В. Райх, - створює можливості терапевтичного впливу «поза свідомістю», що дає змогу знайти причину проблем, отримати доступ до глибинних рівнів несвідомого особистості» [5, с. 187].

Наявність «м'язових панцирів» у структурі особистості спричинює порушення поведінки, неадекватність емоційних проявів, зниження рівня самоконтролю, невротизацію та психопатологічну поведінку. Основні «панцири» можна розподілити на 7 секторів, які включають «утиски» певних органів і їх відповідні функції.

1. Окулярний сектор: очі, мімічні м'язи навколо очей, м'язи лоба. На цьому рівні відбувається блокування контактних реакцій очей, фіксування стресових реакцій, що проявляється в реакціях «порожнього погляду», млявих очей, нерухомого напруженого лоба. Наслідком такого блокування експресивних реакцій є жорсткість і спустошеність погляду, невиразність очей і міміки у верхній третині обличчя, головний біль, погіршення зору, яке можна пов'язати з несвідомим бажанням «не бачити» проблем.

2. Оральний сектор: нижня щелепа, м'язи рота, язик, потилична мускулатура. Цей рівень пов'язаний із пригніченням емоцій плачу та гніву криком, гримасами, регресивними оральними реакціями (смоктанням, кусанням), що супроводжують емоційні реакції, додають волю вербальним контактам і виразність словесній експресії. М'язові блоки виявляються у спазматичних (судомних) реакціях у ділянці рота, напруженості міміки тощо.

3. Шийний сектор: підшкірні і глибокі м'язи шиї. Тут блокуються орієнтовні реакції, супроводжувані поворотами голови, реакції плачу, крику, вербальної агресії, печалі. Проявами блокування у підлітків часто може бути відчуття «кома в горлі», спазматичні та больові симптоми в шийній мускулатурі.

4. Грудний сектор: грудна клітина іруки. Уцій частині відбувається блокування сильних негативних (крик, плач, агресія) і позитивних (сміх, пристрасність) емоцій. На цьому рівні блокується самостверджувальна активність і здатність до досягнення цілей. Основний психологічний зміст блокування на цьому рівні - прояв самоконтролю (надлишкового або недостатність контролю над афективними реакціями), стриманості, безконтактності. Згідно з дослідженнями прихильників напряму тілесноорієнтованої терапії цей сегмент відповідає за утруднення дихання, порушення моторики рук, викривлення постави угрудному відділі хребта.

5. Діафрагмальний сектор: сонячне сплетіння та органи черевної порожнини. На цьому рівні блокуються імпульси, що надходять із нижніх відділів тіла (ділянка тазу) до верхніх, а також тривога, страхи, відчуття образи. Цей рівень пов'язаний із боротьбою в структурі особистості свідомого і підсвідомого, раціонального та «ірраціонального», що спричинює різні особистісні розлади, порушення сприймання навколишньої дійсності.

6. Черевний сектор: м'язи спини. Пов'язаний із пригніченням почуттів страху та агресії. Посилення цього сегмента спричинює труднощі реалізації вітальних функцій, зниження життєвої активності і відчуття загального дискомфорту.

7. Тазовий сектор: м'язи таза і ніг (ноги також можна розглядати як самостійну структурну одиницю). На цьому рівні відбувається блокування сексуальних імпульсів, контроль тривоги, отримання фрустрованої агресивності і прагнення домінувати.

Отже, інтерпретуючи дослідження В. Райха, порушення у секторі «очей» свідчить про страхи підлітка. Проблеми в секторі «рота та шиї» свідчать про наявність порушень сприйняття такої емоції, як гнів. Сектор «грудей» відповідає за радість (зокрема, часто можна спостерігати порушення сміху), тугу, пристрасні емоції (кохання, ненависть). «Діафрагма» перш за все втілює проблеми з гнівом. Сектор «живота» відповідає за порушення таких емоційних станів, як страх, лють, неприязнь, відраза. Порушення у секторі «таза» свідчать про те, що підліток пригнічує такі почуття, як гнів, задоволення, образа.

Із метою визначення сформованості емоційного інтелекту та загального стану емоційної сфери підлітків з порушеннями розумового розвитку методиками тілесно-орієнтованої психології нами було використано методику «Емоційний диктант» (за О. Тарариною).

Підліткам було запропоноване схематичне зображення людини (вид спереду, вид ззаду), на якому необхідно було розмістити почуття, які називав психолог, якщо дитина не могла написати, психолог пропонував показувати, поступово занотовуючи відповіді дитини. Дослідженням було охоплено 125 осіб підліткового віку зі спеціальних загальноосвітніх шкіл-інтернатів м. Києва (школи-інтернату № 17, школи-інтернату № 12 (учні 5-9 класів) та 120 учнів із загальноосвітніх шкіл м. Києва (школи № 149, школи № 168 (учні 5-9 класів). Психодіагностика проводилась відповідно до інструкцій із дотриманням необхідних вимог та використання додаткового інструментарію.

Було встановлено, що більшість емоцій підлітки з порушеннями розумового розвитку зобразили на малюнку в секторі «голова» (табл. 1). Йдеться про те, що підлітки розташовували в секторі «голова» радість, подив, 
відразу, страх, тривогу, печаль; у секторі «серце» - кохання, образу, злість, щастя; у секторі «руки» - дружбу, гнів, тривогу; у секторі «ноги» - страх, тривогу. Таке розташування вказує на блокування емоційних проявів у підлітків, порушення здатності вербалізувати емоції, наявність алекситимічних проявів особистості, амбівалентність емоцій досліджуваних підлітків.

Співставлення більшості емоцій підлітками з порушеннями розумового розвитку в секторі «голова» вказує на особливості презентації підлітка в соціальному оточенні. Отже, можна припустити, що вони схильні сприймати оточуючих і презентувати себе через негативний спектр емоцій. Сектор «груди» відображає емоційний контроль, емоційний баланс, здатність до ефективного самоаналізу, рефлексії, вказує на гармонійний розвиток, прийняття себе та інших. Взагалі це сектор позитивних переживань та емоційно позитивних почуттів: дружби, кохання, турботи тощо. Серед негативних емоцій, що можуть тут розміщуватися, - тривога, страх. У цьому секторі підлітки без порушень розумового розвитку серед негативних почуттів розмістили почуття страху та паніки. Підлітки з порушеннями розумового розвитку серед позитивних почуттів відзначили кохання та щастя, але більшість емоцій, розміщених досліджуваними підлітками, належать до негативного спектра: образа, злість, тривога. Відповідно до цієї методики такий результат вказує на порушення співставлення емоцій та низького рівня емоційного інтелекту, здатності емоційного контролю, рефлексії. За отриманими результатами у підлітків з порушеннями розумового розвитку констатовано перекручування емоцій, амбівалентність почуттів. Сектор «руки» характеризує здатність підлітка виражати емоції, встановлювати соціальні зв'язки, вміння та здатність до комунікабельності. Підлітки з порушеннями розумового розвитку в секторі рук розмістили досить різні за емоційною наповненістю почуття: дружбу, тривогу, гнів. Розміщення саме цих емоцій у секторі «руки» вказує на рефлексивний прояв їх у житті підлітка на рівні неусвідомлюваних реакцій. Сектор «ноги» вказує на сильні емоції, які підліток через несформованість саморегуляційних механізмів не може свідомо контролювати. Часто в цьому секторі підлітки зображають і згадують свої страхи, зокрема страх перед фізичною силою, зневіру в своїх можливостях. Наприклад, сектор «коліна» відповідає саме за саморегуляцію та самоконтроль емоційної сфери. Підлітки, які на малюнку активно використовують цей сектор, характеризуються високим рівнем сугестивності, конформізму. Нижня частина ноги відповідає за мотиваційні механізми підлітка та волю. У підлітків з порушеннями розумового розвитку в секторі «ніг» розташована тривога та страх. Це свідчить про те, що вони не можуть контролювати ці емоції. Страх та тривога часто бувають невмотивованими, не піддаються контролю вольовими зусиллями. Варто відзначити, що у секторі «ноги» у підлітків зі збереженим інтелектом майже немає емоцій.

Тілесно-орієнтована психотерапія після результатів психодіагностики в роботі з підлітками з порушеннями розумового розвитку проходила досить неоднозначно. На перших етапах можна було зустріти низку труднощів, зокрема: підлітки можуть соромитись, вони погано володіють своїм тілом, часто мають порушення просторової орієнтації, незграбні, рухи не плавні, різкі. Варто відзначити, що вправи з тілесно-орієнтованої психотерапії $€$ новим досвідом у житті підлітків, тому вони часто не розуміють інструкції, з першого разу не досить чітко виконують рухи, ігровізавдання.

у тілесно-орієнтованих вправах акцент ставився нами на поєднання емоційно-вольової саморегуляції з тілесними відчуттями в момент переживання тієї чи іншої емоції, розуміння емоційного стану (компонента емоційного інтелекту) підлітком з порушеннями розумового розвитку. Останнім часом методики тілесно-орієнтованої психотерапії виступають складовими частинами інтегративних підходів арт-терапії, які використовуються

Порівняльний аналіз співставлення емоцій із розташуванням їх

Таблиця 1

\section{у тілі підлітками з порушеннями розумового розвитку та підлітками без порушень} розумового розвитку (y \%)

\begin{tabular}{|c|c|c|}
\hline Частина тіла & $\begin{array}{c}\text { Кількість емоцій, що розташовані } \\
\text { в певній частині тіла підлітком } \\
\text { з розумовою відсталістю }\end{array}$ & $\begin{array}{c}\text { Кількість емоцій, що розташовані } \\
\text { в певній частині тіла підлітком } \\
\text { зі збереженим інтелектом }\end{array}$ \\
\hline Голова & 53 & 29 \\
\hline Серце (груди) & 38 & 52 \\
\hline Руки & 21 & 16 \\
\hline Ноги & 13 & - \\
\hline Живіт & - & 16 \\
\hline Спина & - & 7 \\
\hline
\end{tabular}


психологами для подолання певних негативних рис особистості, делінквентних поведінкових реакцій, неадекватних емоційних реакцій особистості. Зокрема, у підлітків з порушеннями розумового розвитку використання такого виду терапії буде доцільним із метою зниження рівня агресивності, психокорекції алекситимічних проявів у підлітків, акцентуйованих рис особистості та невротизації.

Під час психокорекції чи психотерапії певного сектору (частини тіла, яка найбільш після психодіагностики була наповнена негативними почуттями та емоціями) було використано один із таких методів тілесно-орієнтованої терапії у роботі з підлітками з порушеннями розумового розвитку, як: дихання, роботазм'язами (натискування, пощипування тощо), ігри, рухові вправи, обговорення емоційних переживань під час ігор або обговорення больових відчуттів, які не характерні для цього підлітка.

Під час групової роботі в класі можна було помітити, що підлітки проявляють агресивність один до одного. Наприклад, якщо це гра, що пов'язана з плесканням у долоні чи по плечу, вони вдаряли набагато сильніше, ніж цього вимагали правила. Але поряд із цим такі прояви є додатковим психодіагностичним аспектом для психолога щодо стану емоційної сфери та емоційного інтелекту підлітка. З часом у разі повторних проведень ігор, дихальних вправ, обговорень як групових, так і індивідуальних підлітки звикають. Деякі вправи їм подобаються більше, інші, навпаки, не викликають бажання до подальших повторів. Часто вправу, яка найбільше сподобалась (зазвичай це вправа, яка їм вдається або приносить задоволення, радість), вони просять провести ще раз, самі організовують її виконання в позаурочний час. Таким чином підліток з порушеннями розумового розвитку проявляє ініціативу, висловлює свої бажання. У старших підлітків було також помічено здатність до аналізу вправи та порівняння її з власними переживаннями, їх вербалізацію за власною ініціативою. Молодші підлітки не проявляли такої активності, бесіда ініціювалася виключно психологом. Також варто відзначити, що старші підлітки були більше налаштовані на процес виконання тих чи інших вправ, молодші на результат.

Висновки. Дослідження емоційного інтелекту підлітків 3 порушеннями розумового розвитку методами тілесно-орієнтованої психології мають свою специфіку та особливості проведення. Психодіагностика методикою тілесно-орієнтованої психології дала змогу безбар'єрно спілкуватись з підлітком. У процесі діагностики підлітки не закриваються, їх не бентежать довгі питання і тести, що $є$ надзвичайною перевагою для психолога, який одразу може працювати з «Я» підлітка, з його свідомістю. Результатом психодіагностики стала констатація низького рівня сформованості емоційного інтелекту, було виявлено низку перекручених емоцій, неправильно пережитих у досвіді підлітків, виявлено низку характерних «м'язових панцирів» та низький рівень саморегуляції емоційного стану. З огляду на отримані результати основним методом у роботі з емоціями були також методи тілесно-орієнтованої терапії, орієнтовані на вивчення тіла, усвідомлення підлітком тілесних відчуттів, на дослідження того, як потреби, бажання і почуття проявляються у різних тілесних станах, і на навчання відповідних, прийнятних способів вирішення дисфункцій, проблем у цій сфері. Основними напрямами у роботі з емоційною сферою підлітків з порушеннями розумового розвитку були чотири напрями: по-перше, розвиток здатності у підлітка сприймати і «проживати», відчувати емоції (як свої, так і людей зі свого оточення); по-друге, допомога в адекватному спрямуванні негативнихемоцій; по-третє, формування вміння розуміти, що виражає та чи інша емоція; по-четверте, сприяння управлінню емоційним станом на рівні саморегуляційної системи та рефлексії підлітка.

Таким чином, розвиток та корекцію емоційної сфери у підлітків з порушеннями розумового розвитку необхідно здійснювати в аспекті посилення диференційованості переживань, підпорядкування їх розумінню та повному «проживанню» 3 відповідними вербальними символами з метою корекції аликситимії, а також формування та поглиблення вищих емоцій, моральних почуттів.

\section{ЛІТЕРАТУРА:}

1. Байкін Т. Психотерапія дітей з порушеннями психофрізичного розвитку: теорія і практика. Київ : Вид-во НПУ ім. М.П. Драгоманова, 2015. 322 с.

2. Борщевська Г. Воля та емоції у підлітків з порушеннями психофрізичного розвитку: теоретико-методологічний аспект. Харків : Вид-во Інституту технологій та виробництва, 2016. 179 с.

3. Демиренко Г Реабілітація дітей 3 порушеннями психофрізичного розвитку. Харків : ГРИНД, 2010. 144 c.

4. Мороз Б. Сучасні технології реабілітації і навчання підлітків 3 психофізичними порушеннями. Київ : Вид. «А\&Р», 2007. 30 с.

5. Райх В. Анализ личности. Москва : «Ювента», 1999. 333 c.

6. Стариченко В. Тілесно-орієнтовані методи психотерапії в роботі з підлітками: сучасна школа. Львів : Глобус, 2014. 179 с.

7. Goleman, D. Working with emotional intelligence. New York : Bantam Books, 1998.

8. Price D. Some general laws of human emotions: interrelation - ships between intensities of desire, expectation and emotional feeling. 1984. V. 52. Pp. 389-409. 